\title{
Ground-penetrating Radar Accurately Locates Tree Roots in Two Soil Media Under Pavement
}

\author{
Nina Bassuk, Jason Grabosky, Anthony Mucciardi, and Gary Raffel
}

\begin{abstract}
This study involved locating tree roots with a ground-penetrating radar (GPR) system and then examining excavated roots in the same soil volume to compare the accuracy of the GPR system with true root location. In 2003, Acer platanoides 'Emerald Queen' Norway maples were planted in trenches containing two compacted soils (native silt loam and CU-Structural Soil). The trenches were paved with $10 \mathrm{~cm}$ of concrete. In 2008, a GPR system consisting of a $900 \mathrm{MHz}$ antenna mounted on a root-scanning cart was used to conduct linear scans on top of the concrete. Immediately after scanning, the concrete was removed for selected trees and whole root systems were excavated (as an entire system attached to the tree trunk) using an air excavation tool. Regression analysis using mixed effect models showed that the radar reliably predicted root presence in both the native and structural soils. The root count correlations were $r^{2}=0.76$ and $r^{2}=0.81$ for the native and structural soils, respectively. In the compacted native soil under concrete, the radar output overestimated the presence of roots at the minimum detection diameter but did provide a signal associated with root presence at this detection level. In the structural soil under concrete, the radar output reliably predicted roots with only slight overestimation. This study showed that GPR data reliably predicted the presence and locations of roots under the concrete pavement in two compacted soils.

Key Words. CU-Structural Soil; Root Counting; Root Detection; Root Mapping; Root Morphology; Soil Excavation; Virtual Trench.
\end{abstract}

The benefits of conserving trees on urban and community development sites in both new neighborhood developments and in the redevelopment of inner city areas are well known and increasingly quantified (Nowak and Dwyer 2007). Economic benefits such as the reduction of heating and cooling costs, increasing property values and environmental benefits, such as reducing the urban heat island, buffering wind, reducing glare, abating noise, and improving water quality by reducing storm water runoff, are just some of the ways trees improve our lives. Even with the best of intentions, however, trees are often sacrificed in the face of new development. It is difficult to know where tree roots are located to avoid damaging them during construction. Ground-penetrating radar (GPR) is a candidate technology for noninvasively establishing subsurface structural roots layout and creating detailed morphology maps.

GPR is an established noninvasive (i.e., nondestructive) inspection method that has been used worldwide for more than thirty years to locate subsurface objects such as pipes, utilities, and other engineering and environmental targets (Neal 2004). One of the main worldwide uses of GPR is in concrete inspection, where the integrity of the structurally supporting rebars is examined along with the integrity of the concrete matrix itself (Daniels 1996; Conyers and Goodman 1997).

GPR has been shown to successfully locate tree roots noninvasively and in three dimensions in forest soils (Hruska et al. 1997; Butnor et al. 2001; Stokes et al. 2002; Butnor et. al. 2003). The tool has been used to a limited extent underneath pavement (Cermák et al. 2000, cited by Stokes et. al. 2002), while suggesting the need for verification of radar output by direct root excavation. This re- search has shown that GPR can detect roots in favorable (nonclay) soils and a root density estimate can be produced, but detailed root morphology maps were not presented. Although this technology has a long history of use in archaeology and engineering to locate antiquities and utilities (Conyers and Goodman 1997), the practice of using it to map roots in urban soils, which can be compacted, layered and discontinuous, is comparatively new. Before this technology can be used to its fullest, 'ground truth' studies need to be undertaken to explore the limits and resolution of GPR as a tool for locating tree roots on development sites and under pavement.

GPR measurement as a method of mapping tree roots has several advantages over other methods: 1) it is capable of scanning root systems of large trees under field conditions in a relatively short time, 2) it is completely noninvasive and does not disturb the soils or damage the trees examined, 3) being noninvasive, it allows repeated measurements that reveal longterm root system development, 4) it allows observation of root distribution beneath hard surfaces (e.g., concrete, asphalt, bricks, pavers, roads, buildings), and 5) its accuracy is sufficient to detect structural roots with diameters as small as $1 \mathrm{~cm}$.

GPR inspection employs electromagnetic waves, which will reflect, refract and/or diffract from the boundary in a predictable manner when encountering a boundary between objects with different electro-magnetic properties (Daniels 1996). The electromagnetic material property that creates the contrast and causes reflections is the dielectric $(\varepsilon)$, which is a dimensionless quantity relating to the material's behavior when subjected to an electric field. The larger the difference between the di- 
electrics of two different materials, the larger the radar wave. For example, the dielectric of water is 81 and that of an average soil is approximately 13, producing a "dielectric contrast" of 6.2:1 (81/13), which is large and will cause most of the radar wave energy to be reflected back to the surface antenna.

Root detection is possible in principle because of the moisture content within the woody root that provides an excellent contrast with the soil matrix. Roots that are dying will have very little or no moisture content, due to fungal attack for instance, and will be either weak or nonreflective targets and, hence, not detectable. In fact, this is an inferential way to determine root health (Burgess et al. 2001; Shigo 2003). Even roots located in high water table soils are detectable (Gormally et al. 2010).

Although roots are detectable, it may only be possible to estimate a bulk property of the roots structure such as root density (Butnor et al. 2003). However, to create a true root morphology map that shows not only density but also individual roots that are above and below others, bifurcating, merging (grafting), and other means, require considerably more effort. Offline signal analysis software can be employed using properties of the electromagnetic radar wave to "disentangle" the root mass and produce the desired morphology map.

The goal was to use an existing set of installed sidewalks in an experimental grove to ground-truth GPR data collections. The study authors intended to locate tree roots with the GPR system and then count excavated roots in the same soil volume to compare the accuracy of the GPR system with true root location. If GPR technology was found to be accurate, it would be useful to provide data in support of strategies to preserve tree roots during development. By enhancing the ability to retain trees on development sites, GPR technology may enable individuals to maintain and support tree growth in urbanized areas.

\section{MATERIALS AND METHODS}

In the spring of 2003, 72 dormant, lightly branched, bare root liners of Acer platanoides ‘Emerald Queen' (Emerald Queen Norway maple) trees were planted in two soil media in a research field in Ithaca, New York, U.S. The $2 \mathrm{~cm}$ caliper trees were $1.5-2.0 \mathrm{~m}$ tall and were budded onto Acer platanoides seedlings of unknown origin donated by J. Frank Schmidt's Nursery (Boring, Oregon, U.S.).

Six trenches, $24 \mathrm{~m}$ long, $2 \mathrm{~m}$ wide, and $1 \mathrm{~m}$ deep were excavated and the trenches lined on all sides but the bottom with heavy 4 mil plastic. Three trenches were backfilled in three $0.25 \mathrm{~m}$ lifts of silt loam (70\% silt, $23 \%$ clay, $7 \%$ sand), and compacted to 1.7 $\mathrm{Mg} \mathrm{m}^{-3}$. A base course layer of gravel, $0.25 \mathrm{~m}$ deep was laid over the surface of the entire trench and then the trench was paved with $10 \mathrm{~cm}$ of concrete leaving $0.5 \mathrm{~m} \times 0.5 \mathrm{~m}$ openings in the center of 12 equally spaced $2 \mathrm{~m} \times 2 \mathrm{~m}$ squares (Figure 1 ). One liner was planted in each opening in the pavement. The second set of three trenches of the same dimensions was excavated and backfilled in three $0.25 \mathrm{~m}$ lifts with CU-Structural Soil made from $20 \%$ of the same silt loam soil and $80 \% \sim 2.5 \mathrm{~cm}$ limestone gravel by weight. Thirty grams of hydrogel (Gelscape made by Amereq, Inc., New City, NY, U.S.) was added to each $100 \mathrm{~kg}$ of gravel to aid in the uniform mixing of the CU-Structural Soil (hereafter referred to as CU-Soil). The structural soil was compacted to $1.97 \mathrm{Mg} \mathrm{m}^{-3}$, verified by sand-cone replacement method. The same $0.25 \mathrm{~m}$ base course of gravel and $10 \mathrm{~cm}$ of concrete were added on top of the structural soil. Liners were planted in the concrete openings as was done for the trench with the compacted silt loam soil and the trees were watered as necessary. In subsequent growing seasons, the trees were weeded, but there was no additional watering.

In spring 2008, one trench of each treatment was scanned using a TerraSIRch ${ }^{\mathrm{TM}}$ GPR system (Geophysical Survey Systems, Inc., Salem, New Hampshire, U.S.). The GPR system consisted of an SIR-3000 (Subsurface Interface Radar) computer control unit, a $900 \mathrm{MHz}$ (Model 3101B) radar antenna, and a modified tricycle jogging cart for automated scanning as shown in Figure 2. The TreeWin $^{\mathrm{TM}}$ signal processing software package (TreeRadar, Inc., Silver Spring, Maryland, U.S.) was used to process the GPR radar transects offline and produce 2D "virtual trench" maps showing the location (distance along the scan line and depth) of each detected root for each scan line. This customized software package, operating in a semi-automated way with the analyst, permitted root clusters to be "broken up" and individual roots determined.

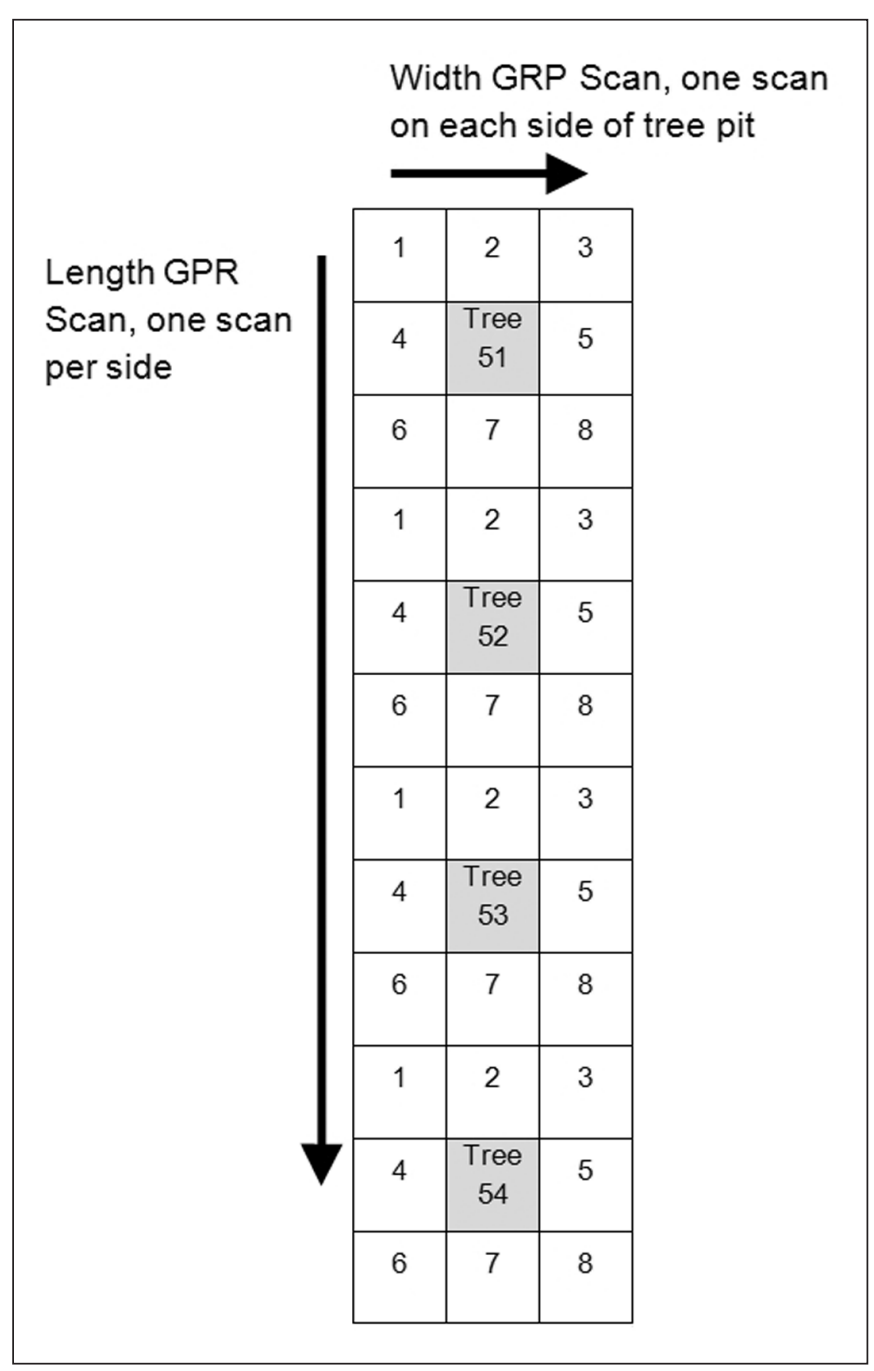

Figure 1. Example layout of sidewalk, GPR paths, and resulting scan sections used in analysis. Trees are surrounded by 8 sampling sections (labeled 1-8). GPR scans ran across the sidewalk as a width scan and along the sidewalk length (labeled long GPR scan). Tree openings were $0.25 \mathrm{~m}^{2}$, and not to scale in the above image. As length and width scans overlapped on corner sections $(1,3,6$, and 8$)$, the two GPR data outputs were averaged in analysis. 


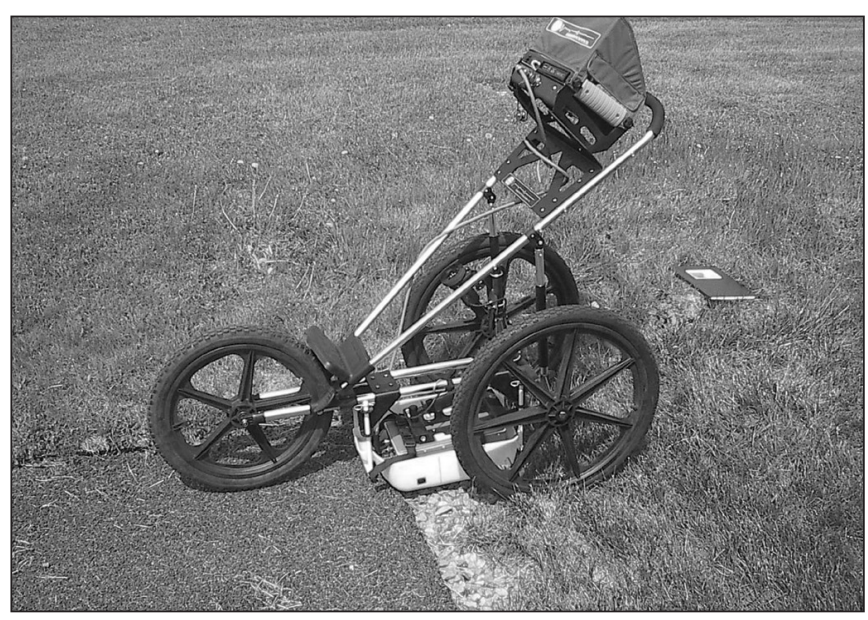

Figure 2. GPR Roots Inspection System. The SIR-3000 Control Computer is at the top with its sun shield. The radar antenna is the module in the white tub (which maintains contact with the ground surface). An encoder wheel rubs against the cart's right rear wheel to provide distance information for automatic data collection.

Calibration of a GPR system is a critical pre-inspection step for roots detection because the signal strength (amplitude) of waves propagating through a medium decreases with increasing depth and causes deeper objects to be less detectable. The SIR3000 system has a means for automatically compensating for this depth-dependent amplitude loss irrespective of the soil surface either bare or covered (e.g., concrete, asphalt, bricks, pavers). The amplitude calibration procedure involves positioning the antenna at various locations within the inspection area, observing a root reflection on the display, and allowing the SIR-3000 to automatically adjust its gain (amplitude) profile to maximize the reflected amplitude from the root. This is repeated at multiple locations and the inspector selects the profile that provides the best overall fit.

The dielectrics of the natural soil and the CU-Soil gravel mix were each empirically found by: 1) locating a root with the GPR system, 2) driving a measuring rod into the soil to find the exact depth, and 3) adjusting the dielectric parameter on the SIR-3000 until the depth scale on the display agreed with the actual depth. This was done at multiple locations within the inspection area and the dielectrics were averaged. The average values found were 13 for the natural soil and 9 for the CU-Soil, which gives a velocity of $8.5 \mathrm{~cm} /$ nsec and $10.2 \mathrm{~cm} / \mathrm{nsec}$ for the natural soil and CU-Soil, respectively. The $20 \%$ higher radar speed in the CU-Soil was most likely due to the higher density of small air pockets.

The GPR system was set to automatically record a radar wave for every $5 \mathrm{~mm}$ of movement along each scan line. This high data collection density, along with the wave's beam width, enabled a root or root cluster to be observed multiple times which enhanced detection sensitivity during data analysis.

A series of $59 \mathrm{~cm}$ wide scans over the concrete paving (between the wheels of the scanning cart unit) were collected by two long scans running the length of the pavement on either side of the tree pit openings, and short scans across the width of the pavement on either side of each tree. As a result, the tree root system was scanned on all four sides of the tree pit opening. Roots in the center opening of the sidewalk were not scanned since the tool could not move through the tree trunk. GPR measurements recorded all root-like signals down to $90 \mathrm{~cm}$. Radar files were divided into sections of output related to the tree pit opening, henceforth termed "scan sections." The process resulted in eight scan sections per tree replicate (Figure 1), four corner sections, and four side sections surrounding a square tree pit opening. Because the scans along the length of the pavement overlapped across the width of the pavement, each corner of the tree root zone included two root signal counts. GPR scanning used a standard setting for the soil system under pavement and an amended setting for the CU-Soil to account for mineral and porosity differences, to keep depth of field accurate.

Immediately after scanning, the concrete was removed from the trenches for the first five trees in each scanned treatment panel. In a protocol similar to Stokes et al. (2002), shoots were removed near ground level and whole root systems were excavated as an entire system attached to the tree trunk using an air excavation tool. The root system was not mapped to test depth inferences between root system and radar depth output. Given the homogenous layers installed under the pavement, mapping of pipes and rubble was not needed. The orientation of the trunk was marked so as to compare it to the GPR scan data when counting roots. After excavation, the root system was skeletonized by removing all roots less than $0.8 \mathrm{~cm}$ in basal diameter and all root axis apices when tapering to a diameter less than $0.8 \mathrm{~cm}$ (Figure 3). The remaining large roots were counted in each section comparable to where the GPR unit made its measurements. No roots that were in the $0.5 \mathrm{~m} \times 0.5 \mathrm{~m}$ opening around the tree trunk were counted. A guide frame constructed of cardboard was placed over the root system to identify that area.

GPR root signals were compared to root counts. Five trees per sidewalk treatment were scanned and excavated, providing 40 sample zones per treatment. Mixed effect models in regression analysis were conducted in JMP v.8 to provide a groundtruth test. Regression plots for data presentation were developed in Minitab 14.2. Since the goal was to evaluate the use of GPR scans in pavement sections as a method of estimating root colonization, GPR data was used as the fixed effect, and the excavated root count as the dependant variable. Random effects included tree individual and pavement section type (the compacted soil versus the compacted CU-soil). The slope of the model outputs were tested against a presumed slope of 1.0 as a calibration guide (one root signal for one root excavated). Paired data were used to explore any discrepancies between radar output and root count. Pavement types were compared for root counts after five years of growth. The mean value for the overlapping scan sections at the corners of each pit were used in the analysis.

\section{RESULTS}

During excavation, it was noticed that no roots were present in the base layer of either treatment. Sample zone root counts and radar output variances within treatment were tested and found to be equal. Differences between radar output and associated root counts in sample zones were found to be normally distributed in the CU-Soil treatment, but not in the compacted soil treatment.

One Way Analysis of Variance of radar output showed an average of 3.3 roots in compacted soil sidewalk sample zones, compared to 5.7 roots in CU-Soil sidewalk zones $(P<0.001)$, which agreed with actual count data of 


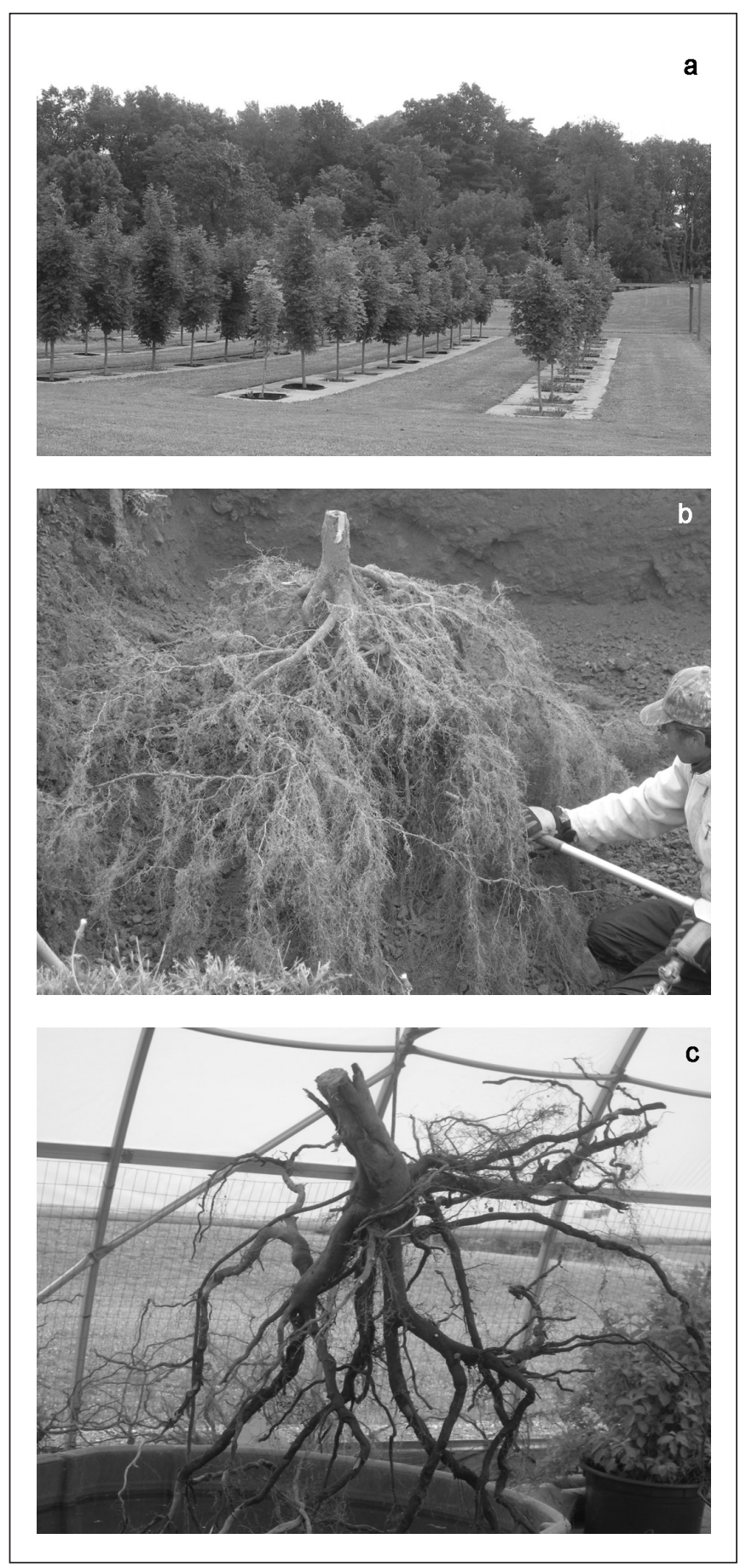

Figure 3. a) Field layout of the tree-sidewalk study plot. b) Air excavation of entire root system grown in CU-Soil. c) Root system during removal of roots $<0.8 \mathrm{~cm}$.

roots $>0.8 \mathrm{~cm}(P<0.001)$ where compacted soil sample zones averaged 2.4 roots compared to 5.9 roots in CU-Soil.

With a combined treatment data set, the radar reliably predicted root presence, but overestimated root count in mixed effect model analysis (Table 1). The random effect of tree individual represented $40 \%$ of model error. The effect was later decomposed into tree effect within the standard soil treatment and a difference in intercept values between the two treatments. The interaction of slope and treatment was not significant $(P=0.8957)$, but followed parallel slopes.

\section{CU-Soil}

Root counts ranged from 2 to 12 roots in a scan section. Paired t-tests results showed that in CU-Soil there was no significant difference between the radar signal and roots count $(P=0.42)$. Regression analysis on 40 sections over the five trees provided a significant linear relationship $(P<0.001)$ between the radar output and actual root counts in excavation (Figure 4). GPR signals reliably predicted, but overestimated root counts (Table 1). Tree individual was not a significant random effect in the model, explaining only four percent of the regression model error. When samples were combined to compare totals by tree (n =5), the model improved (Table 1; Table 2). A 1:1 slope was not rejected by the model, but there was a higher initial offset constant between root signal and root count. There was a higher degree of error at the whole-tree level of analysis, which may be a reflection of the small replicate number ( 5 trees), or alternatively in the additive error from the four radar scanning paths used per tree. The constant was not significantly different than zero, but was also associated with a larger error.

\section{Compacted Silty Clay Loam Soil}

Root counts ranged from zero to 8 roots in a scan section. Tree replicate 5 had the three highest scan section root counts $(5,6$, and 8 roots). In the compacted soil, radar signal counts exceeded root counts in 21 of the 40 scan sections and were equivalent in 17, providing a significant difference $(P<0.001)$. Regression analysis on 40 matched zones over the five trees provided a significant linear relationship $(P<0.001)$ between the radar output and actual root counts in excavation (Figure 5; Table 1). The constant was not significantly different than zero, and the slope showed an overestimation of roots by the radar output. Tree individual was a

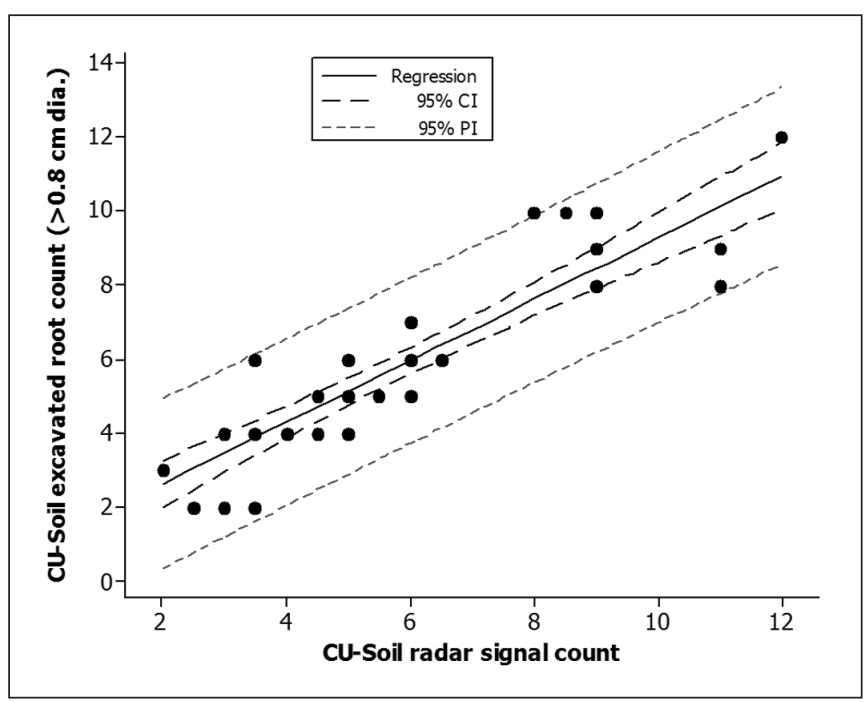

Figure 4. Regression output showing confidence and prediction intervals for a relationship in CU-Structural Soil comparing ground-penetrating radar output to excavated actual root counts ( $N=\mathbf{4 0}$ measurement sections, not all data points visible due to overlap). Relationship shown: excavated root count $=0.97+0.83$ radar signal count; $\mathrm{r}^{2}=0.81$ 


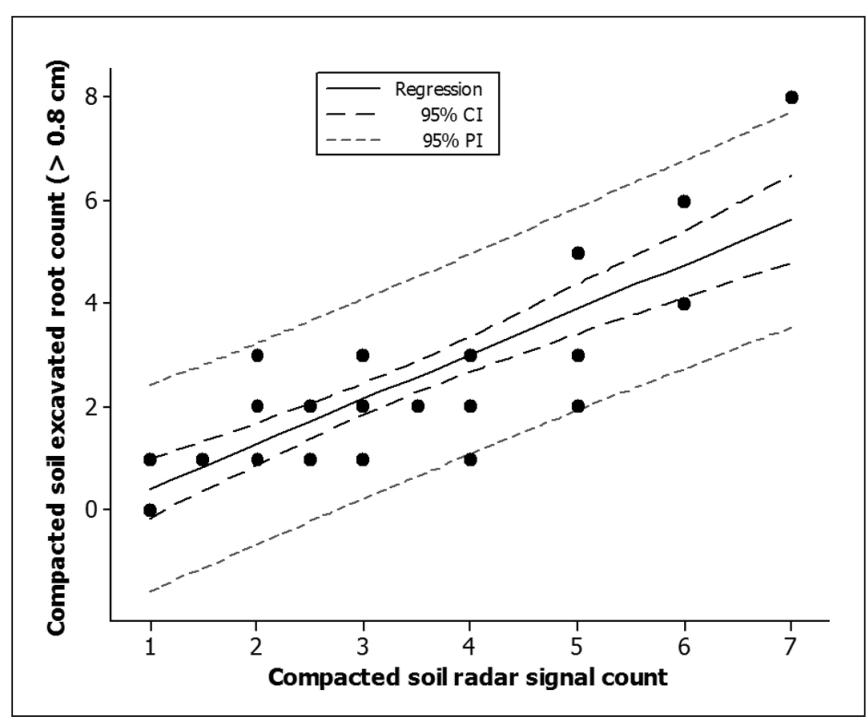

Figure 5. Regression output showing confidence and prediction intervals for a relationship in compacted soil comparing ground penetrating radar output to excavated actual root counts $(\mathrm{N}=40$ measurement sections, not all data points visible due to overlap). Relationship shown: Excavated root count $=\mathbf{- 0 . 1 2}+0.77$ radar signal count; $r^{2}=0.76$. significant random effect in the model due to tree replicate 5 . Tree 5 had a constant value of 1 root greater in excavated root count when compared to its related GPR readout. Scan sections were combined to compare totals by tree $(n=5)$ from data in Table 2 .

\section{DISCUSSION AND CONCLUSIONS}

GPR data reliably predicted the presence of roots under the pavement and provided a reasonably accurate root count in the compacted soil treatment under concrete pavement. In the CUSoil designed for use under pavement, the root zone layer was more homogenous before and after compaction, which could simplify analysis of root mapping outputs. With a designed porosity after compaction to ensure interconnected voids for root growth (Grabosky et al. 1996), larger roots may require less energy investment to colonize the root zone layer in the pavement system. If so, the CU-Soil material allowed a greater number of roots to occur that were large enough to generate a radar signal.

Radar scanning with different energy frequencies or more expensive multiple antennae units might provide data with a greater resolution or finer detail (Danjon et al. 1999; Utsi 2000). A multiple-scan or grid scanning approach with 3D image analysis, as used in other field studies, may provide mapping capability (Hruska et al. 1997; Stokes et al. 2002; Butnor et al. 2003; Nadezhdina and Cermák 2003). However, in the CUSoil, which is a predominately stone mixture, it is important to

Table 1. Regression models to relate excavated root counts of trees in two pavement treatments as compared to ground penetrating radar counts of root signals. As a ground-truth verification study, the expected slope would be equal to 1 (one root for each signal) with an intercept of zero. In the regression models presented, $y=$ excavated root count, and $x=G P R$ count.

\begin{tabular}{|c|c|c|c|c|c|c|c|}
\hline Model & Equation & $\mathrm{n}$ & $\begin{array}{l}\text { S.E. } \\
\text { slope }\end{array}$ & $\begin{array}{l}\mathrm{p} \text {-value } \\
\mathrm{H}_{\mathrm{o}} \text { slope }=1.0\end{array}$ & $\begin{array}{l}\text { S. E. } \\
\text { constant }\end{array}$ & $\begin{array}{l}\text { p-value } \\
\mathrm{H}_{\mathrm{o}} \text { constant }=0\end{array}$ & $r^{2}$ \\
\hline $\begin{array}{l}\text { Experiment-wide } \\
\text { (mixed effect model) }\end{array}$ & $y=0.84 x+0.26$ & 80 & 0.05 & 0.004 & 0.36 & 0.4765 & 0.88 \\
\hline \multicolumn{8}{|l|}{ CU-Soil } \\
\hline scan section & $y=0.83 x+0.97$ & 40 & 0.07 & 0.022 & 0.46 & 0.435 & 0.81 \\
\hline tree & $y=0.96 x+3.8$ & 5 & 0.23 & 0.87 & 10.21 & 0.735 & 0.86 \\
\hline \multicolumn{8}{|l|}{ Silt loam } \\
\hline scan section & $y=0.77 x-0.12$ & 40 & 0.09 & 0.017 & 0.43 & 0.7846 & 0.76 \\
\hline tree & $y=2.13 x-40.6$ & 5 & 0.95 & 0.30 & 26.1 & 0.217 & 0.63 \\
\hline
\end{tabular}

Table 2. Whole-tree (as total of eight count zones) root radar signal count versus actual root count. Positive numbers are overestimation of root count by radar and negative numbers are underestimation of root count by radar. Zero would be parity in grand totals between radar signal and root count, but not necessarily within count zones.

\begin{tabular}{llllll}
\hline Tree replicate & 1 & 2 & 3 & 4 & 5 \\
\hline CU-Soil & & & & & \\
$\quad$ excavated root count & 38 & 57 & 43 & 49 & 47 \\
$\quad$ radar signal count & 40 & 56 & 39 & 45 & 43 \\
$\quad$ difference & 2 & -1 & -4 & -4 & -4 \\
& & & & & \\
Compacted soil & 12 & 10 & 17 & 17 & 33 \\
$\quad$ excavated root count & 28 & 26 & 25 & 25 & 33 \\
$\quad$ radar signal count & 16 & 16 & 8 & 8 & 0 \\
$\quad$ difference & & & & & \\
\hline
\end{tabular}

have a successful ground-truth result since previous authors have suggested problems in differentiating roots from stones in GPR applications in forest soils (Daniels 1996; Butnor et. al. 2003).

In compacted native soil, the radar output repeatedly overestimated the presence of roots at the minimum detection diameter. To be clear, the unit did provide a signal associated with root presence. However, the compacted silty clay loam soil was massive in structure with a few small cracks colonized by multiple roots of very small diameter, which were observed and later removed in the post-excavation process. The study authors suggest that the clustering of such roots in close proximity resulted in a radar signal that has been observed in other studies (Hirano et al. 2009). This cluster would be detectable even if the individual roots were not. Consequently, when these roots were removed during the skeletonizing procedure, the actual count would not consider these clusters whereas the radar count would. This could contribute to the overestimation. It is thus suggested that as a diagnostic tool in compacted soils un- 
der pavement, the radar unit can detect root presence, but some care and further site data should improve interpretation.

It has been observed in forest soils that fast-draining sands provide better signal interpretation when compared to Piedmont clays (Butnor et al. 2001). The current study likely reflects extremes in such conditions with an advantage in soils where root growth is unimpeded.

Multiple parallel scans with this radar system could be used to link root signal traces to develop a growth axis trajectory through a signal density, or direct signal pairing method between scans. The controlled layer thicknesses of varied materials in pavement section design can allow an operator to adjust the depth of view. Shifts in signal outputs at each layer interface can allow a reliable depth of field adjustment to provide accurate root depth. This accuracy was not tested here due to the unsupported sagging of the roots once excavated during the skeletonizing process.

In conclusion, there have been concerns with a general lack of controlled, replicated studies designed to validate ground-penetrating radar output with actual root counts, due to the difficulty and expense of generating such data. This study fills this need and shows that ground-penetrating radar can be used accurately to identify root presence, if not size, in both a compacted soil and a stone-soil mixture when scanned through a concrete pavement. It points out the need for caution in any interpretation of the nature of the root colonization in soils with massive structure. In the designed nature of an urban pavement system, other aspects of infrastructure are mapped and verified in a fairly defined underground environment. Therefore, it is reasonable to suggest roots can be detected and mapped using GPR with the proper scanning approach and analysis, much as in other published tree root-GPR studies.

\section{LITERATURE CITED}

Burgess, S., M. Adams, N. Turner, D. White, and C. Ong. 2001. Tree roots: Conduits for deep recharge of soil water. Oecologia 126:158-165.

Butnor, J.R., J.A. Doolittle, L. Kress, S. Cohen, and K.H. Johnsen. 2001. Use of ground-penetrating radar to study tree roots in the southeastern United States. Tree Physiology 21:1269-1278.

Butnor, J.R., J.A. Doolittle, K.A. Johnsen, L. Samuelson, T. Stokes, L. Kress. 2003. Utility of ground-penetrating radar as a root biomass survey tool in forest systems. Soil Science Society of America Journal 67:1607-1615.

Cermák, I., J. Hruska, M. Martinkova, and A. Prax. 2000. City tree roots and survival near houses analyzed using sap flow and ground penetrating radar technique. Plant Soil 219:103-116.

Conyers, L.B., and D. Goodman. 1997. Ground-Penetrating Radar: An Introduction for Archaeologists. AltaMira Press, ISBN 0-7619-8928-5.

Daniels, D.J. 1996. Surface-Penetrating Radar. The Institute of Electrical Engineers, ISBN 0-85296-862-0.

Danjon, F., H. Sinoquet, C. Godin, F. Colin, and M. Drexhage. 1999. Characterization of structural tree root architecture using 3D digitizing and AMAPmod software. Plant Soil 211:241-258.

Gormally, K., M. McIntosh, and A. Mucciardi. 2010. Calibrating groundpenetrating radar detection and 3D mapping of preferential flow pathways: I. Calibration. Soil Science Society of America Journal, in press.
Grabosky, J., N. Bassuk, and H. van Es. 1996. Further testing of rigid urban tree soil materials for use under pavement to increase street tree rooting volumes. Journal of Arboriculture 22(6):255-263.

Hirano, Y., M. Dannoura, K. Aono, T. Igarashi, M. Ishii, K. Yamase, N. Makita, and Y. Kanazawa. 2009. Limiting factors in the detection of tree roots using ground-penetrating radar. Plant and Soil 319:15-24.

Hruska, J., I. Cermák, and S. Sustek. 1997. Mapping of tree root systems with ground penetrating radar. Tree Physiology 19: 125-130.

Nadezhdina, N., and I. Cermák. 2003. Instrumental methods for studies of structure and function of root systems of large trees. Journal of Experimental Botany 54(387):1511-1521.

Neal, A. 2004. Ground penetrating radar and its use in sedimentology: principles, problems and progress. Earth-Science Reviews 66:261-330.

Nowak, D.J., and J.F. Dwyer. 2007. Understanding the benefits and costs of urban forest ecosystems In: J.E. Kuser (Ed.). Urban and community forestry in the northeast 2 nd edition. pp. 25-46.

Shigo, A. 2003. Modern Arboriculture. Shigo and Trees, Associates Press. ISBN 0-943563-09-7.

Stokes, A., T. Fourcaud, J. Hruska, I. Cermák, V. Nadyezdhina, and L. Praus. 2002. An evaluation of different methods to investigate root system architecture of urban trees in situ: I. ground-penetrating radar. Journal of Arboriculture 28(1):2-10.

Utsi, V. 2000. Development and different modes of operation of a multireceiver ground penetrating radar system. In: D.A. Noon, G.F. Stickley, and D. Longstaff (Eds.). Proc. Eighth Int. Conf. on Ground Penetrating Radar. SPIE Vol. 4084, Washington, D.C., pp. 351-355.

Nina Bassuk (corresponding author)

Professor

Dept. of Horticulture

Cornell University

Ithaca, NY 14853, U.S.

NLB2@cornell.edu

Jason Grabosky

Associate Professor

Dept. of Ecology, Evolution and Natural Resources

Rutgers University

New Brunswick, NJ 08901, U.S.

Anthony Mucciardi

President

TreeRadar, Inc.

Silver Spring, MD 20910, U.S.

Gary Raffel

ISA Certified Arborist

Dynamic Tree Systems

Bloomfield, NY 14469, U.S. 
Résumé. Cette étude concerne un projet de localisation des racines d'arbre au moyen d'un système de radar à pénétration dans le sol ainsi qu'une comparaison des données recueillies par rapport à la réalité observée suite à l'excavation du même volume de sol dans le but d'analyser le degré de précision du système radar. En 2003, des Acer platanoides 'Emerald Queen' ont été plantés dans des tranchées remplies de deux type de sol compactés différents (un loam limoneux naturel et un sol structural). Les tranchées ont été recouvertes d'une couche de $10 \mathrm{~cm}$ d'épaisseur de béton. En 2008, un système de radar à pénétration dans le sol muni d'une antenne de $900 \mathrm{MHz}$ montée sur un véhicule de reconnaissance a été utilisée afin de mener des scans linéaires sur le dessus de la couche de béton. Immédiatement après les scans, la couche de béton a été enlevée au-dessus des arbres sélectionnés et la totalité du système racinaire a été excavée au moyen d'un excavateur à air. Une analyse de régression employant des modèles à effet mixte a permis de démontrer que le radar s'est avéré efficace pour prédire la présence des racines à la fois au sein du sol naturel que du sol structural. Les corrélations obtenues étaient de $r^{2}=0,76$ et de $r^{2}=0,81$ respectivement pour le sol naturel et le sol structural. Pour le sol naturel compacté sous une dalle de béton, les données provenant du radar ont surestimé la présence des racines lorsqu'on était en présence de racines dont le diamètre était au minimum détectable, mais le signal indiquait malgré tout que des racines de cette catégorie étaient présentes. Pour le sol structural sous une dalle de béton, le radar permettait de détecter de manière fiable la présence des racines avec seulement une légère surestimation. Cette étude a permis de démontrer que les données provenant du système de radar à pénétration dans le sol permettaient de détecter de manière fiable la présence et la localisation des racines sous une couche de béton au sein de deux types différents de sols compactés.

Zusammenfassung. Diese Studie verband die Lokalisierung von Baumwurzeln durch ein bodendurchdringendes Radarsystem und die anschließende Untersuchung der ausgegrabenen Wurzeln in demselben Bodenabschnitt, um die Genauigkeit des Radarsystems bei einer realitätstreuen Wurzelauffindung zu vergleichen. In 2003 wurden Acer platanoides 'Emerald Queen'-Bäume in Beeten mit zwei verdichteten Böden (natürlicher Lehm und CU-Strukturboden) gepflanzt und verglichen. Die Beete waren mit $10 \mathrm{~cm}$ Beton gepflastert. In 2008 wurde ein GPR-System mit einer $900 \mathrm{MHz}$-Antenne auf einen Wurzelauffindungswagen montiert, um lineare Messungen auf dem Beton durchzuführen.
Sofort nach der Messung wurde der Beton für ausgewählte Bäume entfernt und das ganze Wurzelsystem mit einem Luftexkavationsgerät ausgegraben (als ein zusammenhängender Wurzelstock am Stamm). Die Regressionsanalyse, die gemischte Effektmodelle anwendete, zeigte, dass das Radar verlässlich die Anwesenheit von Wurzeln in dem natürlichen und dem strukturellen Boden anzeigen konnte. Die Korrelationen der Wurzelzählung waren $\mathrm{r}^{2}=0.76$ und $\mathrm{r}^{2}=0.81$ für den natürlichen und den Strukturboden. In dem verdichteten natürlichen Boden unter dem Beton überschätzte das Radar die Anwesenheit von Wurzeln bei einem Minimum an Nachweisdurchmesser, aber es lieferte ein Signal, welches mit der Anwesenheit von Wurezln in diesem Level assoziiert werden konnte. In dem Strukturboden unter dem Beton konnte das Radar die Wurzeln sicher und nur mit geringer Überschätzung vorhersagen. Diese Studie zeigte, dass die GPR-Daten verlässlich die Anwesenheit von Wurzeln unter Betonpflaster in zwei verdichteten Böden vorhersagen können.

Resumen. Este estudio trató de la localización de raíces de los árboles con un sistema de radar de penetración del terreno (GPR) y el examen de las raíces excavadas en el mismo volumen de suelo para comparar la precisión del sistema GPR con la localización real de las raíces. En 2003, árboles de maple de Acer platanoides 'Emerald Queen' Norway fueron plantados en zanjas con dos suelos compactados (nativo franco-limoso y suelo estructural). Las zanjas fueron pavimentadas con concreto de 10 cm. En 2008, un sistema GPR consistente de una antena de $900 \mathrm{MHz}$ montada en una tabla escáner de raíces fue usada para levantar escaneos lineales arriba del concreto. Inmediatamente después del escaneo, el concreto fue removido para los árboles seleccionados y el sistema de raíces completo fue excavado (como un sistema entero atado al tronco del árbol) usando un herramienta o pala de aire. El análisis de regresión de los modelos usados mostró que el radar predijo la presencia de raíces en los dos tipos de suelos: nativo y estructural. Las correlaciones del conteo de raíces fueron $\mathrm{r} 2=0.76$ y r $2=0.81$ para los suelos nativo y estructural, respectivamente. En el suelo nativo compactado bajo concreto, las salidas del radar sobrestimaron la presencia de raíces a un diámetro mínimo de detección pero dio una señal asociada con la presencia de raíces a este nivel de detección. En el suelo estructural bajo concreto, el radar predijo las raíces con solamente una leve sobrestimación. Este estudio mostró que los datos del sistema GPR predicen confiablemente la presencia y localización de raíces bajo pavimento de concreto en dos suelos comparados. 